\title{
KONSEP PERCAYA DIRI DALAM AL QUR'AN DAN IMPLIKASINYA TERHADAP KEHIDUPAN MANUSIA
}

\author{
Achmad Suhaili \\ Email: ahmadsuhaili63494@gmail.com \\ Sekolah Tinggi Ilmu Al Qur'an Wali Songo Situbondo
}

\begin{abstract}
Abstrak
Self-confidence is an aspect of the human personality that functions important to actualize its potential. Without self-confidence, many problems will arise in humans. With the presence of confidence, someone will get along easily. Facing people who are older, smarter and richer, they are not ashamed to be awkward. They will dare to show themselves as they are, without prominently-highlighting excesses and covering up shortcomings. This is because people who are confident have truly understood and trusted their condition, so that they have been able to accept their condition as they are.

Does the Qur'an talk about the concept of self-confidence? And how does the Qur'an talk about the concept of self-confidence? Of course there is no verse of the Qur'an that speaks of self-confidence lexically "al tsiqah bi al nafs" translation from confidence. However, there are many verses of the Qur'an that talk about human concepts according to the Qur'an and calls to believe in their ability to change, never be afraid and worried, do not be anxious and so on that need to be assessed thematically. According to Izzatul Jannah, the higher a person's faith, the higher the level of confidence. In the Qur'an it is stated that self-confidence in the form of a comfortable feeling of peace, without feeling sad, afraid and worried will come to those who believe in Allah swt. "Those who say:" Our Lord is God "then they affirm their position, the angels will come down to them (by saying): "Do not be afraid and do not feel sad; and delight in (obtaining) the heaven that God has promised you "(Fusshilat: 30) Confidence in the Qur'an starts from a noble conception of mankind, namely the Khalifah of Allah, the best of creatures, and creatures that are free of will. The concept of self-confidence in the Qur'an begins with having a Self Concept (Ma'rofatun Nafsi), Positive Thinking, Faith and Charity, Tawakalkepada Allah, Gratitude, and Muhasabah (Self Evaluation).
\end{abstract}

Keyword: Confidence, Positive Thinking

\section{A. Pendahuluan}

Kepercayaan diri merupakan aspek kepribadian manusia yang berfungsi penting untuk mengaktualisasikan potensi yang dimilikinya. Tanpa adanya kepercayaan diri maka banyak masalah akan timbul pada manusia. ${ }^{1}$ Dengan adanya rasa percaya diri maka seseorang akan mudah bergaul. Menghadapi orang yang lebih tua, lebih pandai maupun lebih kaya, mereka tidak malu mau pun canggung. Mereka akan berani menampakkan dirinya secara apa adanya, tanpa menonjol-nonjolkan kelebihan serta menutup-nutupi kekurangan. Ini disebabkan orang-orang yang percaya diri telah benar-benar memahami

\footnotetext{
${ }^{1}$ Tina Afiatin, dan Sri Mulyani Martaniah, Peningkatan Kepercayaan Diri Remaja Melalui Konseling Kelompok.dalam Jurnal Psikologika (Yogyakarta:Fakultas Psikologi UII, 1998), No.6. 1998 hal.66.
} 
dan mempercayai kondisi dirinya, sehingga telah bisa menerima keadaan dirinya apa adanya. $^{2}$

Fenomena tutup mulut,tidak mau berbicara yang terjadi pada mahasiswa untuk mengungkapkan pendapatnya ketika terjadi diskusi bukanlah sikap dan tindakan yang dapat memajukan keilmuan bagi dirinya.Sikap seperti ini dapat terjadi disebabkan oleh minimnya percaya diri. Karena pada dasarnya ia ingin melakukan itu akan tetapi karena tidak percaya diri maka diam saja, karena perasaan takut, cemas, minder sehingga sesudah itu, akan menyesali keadaannya yang tidak mampu berbicara dan mengungkapkan apa yang ada dibenaknya. Apalagi, ketika apa yang ingin diungkapkan tersebut ternyata disampaikan oleh orang lain maka ia langsung menyesali tindakan diam yang diambilnya.

Berdakwah adalah aktivitas mulia.Allah memuji para da'i sebagai orang-orang yang memiliki perkataan paling baik.Akan tetapi, banyak umat Islam yang tidak percaya diri melakukan tugas mulia ini.Bahwa pe-de (percaya diri) itu hampir selalu dikaitkan dengan kesuksesan, tak dapat disangkal.Ia memang bekal utama dalam menghadapi tantangan hidup. ${ }^{3}$

Teori-teori psikologi banyak mengungkap tentang fenomena ini berdasarkan pandangan mereka terhadap kepribadian manusia.Percaya diri muncul dari konsep dan citra diri yang dimiliki oleh setiap orang. Teori kepribadian eksistensialis mengungkapkan bahwa seperti apa manusia membayangkan maka seperti itulah ia. Teori kepribadian behavioris menegaskan bahwa manusia adalah hasil dari pengaruh-pengaruh di sekelilingnnya. Teori keperibadian psikoanalisa menjelaskan bahwa setiap manusia adalah totalitas dari mana ia bergantung berkembang sendiri. Dan teori aktualisasi diri menjelaskan bahwa manusia adalah realisasi dari potensinya yang terbesar. ${ }^{4}$ Percaya diri muncul dari bagaimana seseorang memandang dirinya.

Al-Qur'an, sebagai kalamullahatau mukjizatul Islam yang diturunkan Allah kepada Nabi Muhammad SAW untuk seluruh manusia. Ajaran Islam, merupakan rahmat bagi seluruh alam semesta, rahmatan lilalamin.Pada hakikatnya, al-Qur'an telah berbicara tentang seluruh persoalan manusia yang berupa prinsip-prinsip dasar.

Al-Qur'an berbicara kepada akal dan perasaaan manusia; mengajar mereka tentang aqidah tauhid; membersihkan jiwa mereka dengan berbagai praktek ibadah; memberi mereka petunjuk untuk kebaikan dan kepentingannya, baik dalam kehidupan individu maupun sosial; menunjukkan kepada mereka jalan terbaik, guna mewujudkan jati dirinya, mengembangkan kepribadiannya dan meningkatkan dirinya menuju kesempurnaan insani, sehingga mampu mewujudkan kebahagiaan bagi dirinya, di dunia dan akhirat. ${ }^{5}$ Al-Qur'an sebagai rujukan pertama juga menegaskan tentang percaya diri dengan jelas dalam beberapa ayat-ayat yang mengindikasikan percaya diri seperti:

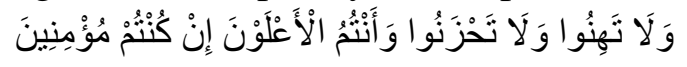

\footnotetext{
${ }^{2}$ http://www.hidayatullah.com/sahid/9901/marah.htm

${ }^{3}$ http://www.indomedia.com/Intisari/2000/februari/pede.htm

${ }^{4}$ Budi Wiyarno, Be Your Self, makalah pada seminar Becoming Self Confident di Universitas Ahmad Dahlan Yogyakarta. 2002

${ }^{5}$ Muhamad Usman Najati, Al-Qur'an dan Psikologi. Alih Bahasa: Tb. Ade Asnawi Syihabuddin (Jakarta: Aras Pustaka, 2002), hal. ix.
} 
Janganlah kamu bersikap lemah, dan janganlah (pula) kamu bersedih hati, padahal kamulah orang-orang yang paling tinggi (derajatnya), jika kamu orang-orang yang beriman. (Ali Imran: 139)

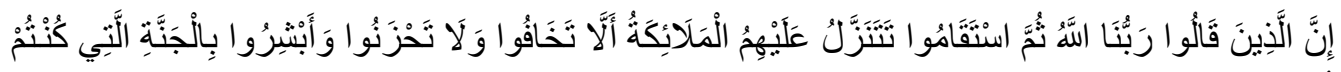
تُؤَعَدُونَ

Sesungguhnya orang-orang yang mengatakan: "Tuhan kami ialah Allah" kemudian mereka meneguhkan pendirian mereka, maka malaikat akan turun kepada mereka (dengan mengatakan): "Janganlah kamu merasa takut dan janganlah kaти merasa sedih; dan bergembiralah kamu dengan (memperoleh) surga yang telah dijanjikan Allah kepadamu". (Fusshilat: 30).

Ayat-ayat di atas dapat dikategorikan dengan ayat yang berbicara tentang persoalan percaya diri karena berkaitan dengan sifat dan sikap seorang mukmin yang memiliki nilai positif terhadap dirinya dan memiliki keyakinan yang kuat.

Dari ayat di atas nampak bahwa orang yang percaya diri dalam al-Qur'an di sebut sebagai orang yang tidak takut dan sedih serta mengalami kegelisahan adalah orang orang yang beriman dan orang-orang yang istiqomah.Banyaknya ayat-ayat lain yang menggambarkan tentang keistimewaan kedudukan manusia di muka bumi dan juga bahkan tentang keistimewaan umat Islam, yang menurut penulis merupakan ayat-ayat yang dapat dipergunakan untuk meningkatkan rasa percaya diri.

Ma'rifatunnafsi atau mengenal diri sendiri terkenal dengan ungkapan "barang siapa yang mengenal dirinya, maka ia mengenal Tuhannya", Dapat disejajarkan dengan konsep diri, self concept yaitu bagaimana seseorang memandang dirinya sendiri.Khusnudzon atau prasangka yang baik juga dapat disejajarkan dengan berpikir positif. Kata-kata yang terus beriringan dalam al-Quran yaitu iman dan amal merupakan penegasan dari harus adanya keyakinan dan tindakan. Untuk menyikapi semua tindakantindakan dan hasil yang diperoleh atas semua usahanya Islam memberikan konsep lain seperti tawakal, syukr dan muhasabah yang harus diamalkan dalam kehidupan seharihari. Akumulasi konsep-konsep tersebut jika diteliti secara berkesinambungan akan menimbulkan dan mengisyaratkan adanya konsep percaya diri yang terungkap dalam alQur'an.

Sirah Rasullulah dan para sahabat yang hidup pada masa kejayaan Islam merupakan kisah yang marak dengan bukti-bukti kepercayaan diri umat Islam dalam menghadapi umat atau individu lain. Kisah-kisah tentang Rasulullah dan para sahabat ini tentunya juga dapat dijadikan objek kajian sebagai perbandingan bagaimana kepribadian Rasul dan generasi awal yang berpegang teguh kepada al-Qur'an dan Sunnah.Sehingga akhirnya mereka mampu membawa Islam menuju zaman keemasan.

Pada akhirnya, konsep-konsep kepribadian yang dikemukakan oleh berbagai aliran psikologi, karena teori-teori ini berasal dari masyarakat budaya "Barat" yang diyakini sedikit banyak, berbeda dari masyarakat "Timur" ada kemungkinan teori yang 
mereka sampaikan terasa asing bagi masyarakat timur ${ }^{6}$ atau bahkan bertentangan dengan konsep-konsep Islam. Maka perlu kiranya bagi ilmuwan Muslim untuk mencari konsepkonsep tersebut dengan mengggunakan tolok ukur yang telah ditentukan oleh al-Qur'an dan Sunnah agar tidak terjebak ke dalam "lubang biawak". ${ }^{7}$ Dengan bertitik tolak pada konsep al-Qur'an akan dapat dipahami bagaimana ajaran Islam terhadap konsep-konsep keilmuan yang dalam hal ini adalah konsep percaya diri.

\section{Pengertian Percaya Diri}

Asumsi umum yang berkembang bahwa memiliki kepercayaan diri berarti meyakini kemampuannya dalam melakukan hal-hal tertentu. ${ }^{8}$ Seorang da'i yang sudah terbiasa melakukan dakwah dengan lisan di masjid-masjid atau acara-acara seremonial keagamaan merasa meyakini dirinya mampu untuk berdakwah. Dalam anggapan umum, dia sering dianggap seorang yang percaya diri karena mampu melakukannya di depan orang banyak. Kemampuan ini sering diasumsikan dengan percaya diri. Sementara di lain waktu, ketika dituntut untuk menulis sebuah buku tentang konsep dakwah seringkali merasa tidak mampu. Begitu juga dengan kemampuan dan keahlian lain seperti berdakwah, menulis, mengajar, bisnis, dan lain sebagainya akan timbul percaya diri untuk melakukannya apabila sudah mampu, memiliki keahlian dan sukses di dalam bidang tersebut. Sementara keinginan untuk melakukan tindakan-tindakan lain yang dapat mengembangkan potensi dalam dirinya selalui dihantui dengan perasaan ketakutan, minder, dan perasaan malu.

Jika kepercayaan diri seperti ini, maka rasa percaya diri itu hanya timbul pada saat mengerjakan sesuatu yang mampu dan sudah biasa untuk dilakukan, sementara dalam melakukan tindakan-tindakan lain yang baru akan timbul rasa enggan, takut dan perasaan lainnya yang negatif. Oleh karena itu perlu dicari apa makna percaya diri sesungguhnya yang dapat meningkatkan harga diri dan konsep diri positif.

Menurut Barbara De Anggelis: "Kepercayaan diri adalah sesesuatu yang harus mampu menyalurkan segala yang kita ketahui dan segala yang kita kerjakan". ${ }^{9}$ Masih menurutnya, kepercayaan diri sejati tidak ada kaitannya dengan kehidupan lahiriah seseorang.Ia terbentuk bukan dari apa yang diperbuat, namun dari keyakinan diri, bahwa setiap yang dihasilkan olehnya memang berada dalam batas-batas kemampuan dan keinginan pribadi. ${ }^{10}$ Dari penjelasan Barbara di atas, percaya diri merupakan keyakinan dalam jiwa manusia bahwa tantangan hidup apapun harus dihadapi dengan berbuat sesuatu, bukan kepada kemampuan, keahlian, hasil dan kesuksesannya tetapi pada kesedian untuk melakukannya.

Menurut Akrim Ridha, tsiqah(kepercayaan atau confidensi) adalah kepercayaan manusia akan: (1) cita-cita hidup dan keputusan-keputusannya, dan (2) potensi dan segala

11.

${ }^{6}$ A. Supratikya, Teori-Teori Holistik (Organismik-Fenomenologis), (Yogyakarta: Kanisius, 1993) hlm. ${ }^{8}$ Barbara De Angelis, Confidence, Percaya diri, Sumber Sukses dan Kemandirian (Jakarta: Gramedia Pustaka Utama, 2002), hal. 3.

${ }^{9}$ Ibid, hal. 5 .

${ }^{10}$ Ibid, hal 9. 
kemungkinan dari dirinya, atau dapat diistilahkan dengan al iimaan bidzaatihi yaitu kepercayaan terhadap kemampuannya. ${ }^{11}$ Maksudnya adalah bahwa orang yang percaya diri adalah orang yang meyakini bahwa ia adalah orang yang memiliki cita-cita dan yakin bahwa ia mampu untuk melakukan sikap-sikap dan tindakan-tindakan untuk mewujudkan cita-citanya itu.

Menurut Jacinta F Rini dari team e-psikologi menjelaskan kepercayaan diri adalah sikap positif seorang individu yang memampukan dirinya untuk mengembangkan penilaian positif baik terhadap diri sendiri maupun terhadap lingkungan atau situasi yang dihadapinya.Dengan memiliki ini menurutnya bukan berarti bahwa individu tersebut mampu dan kompeten melakukan segala sesuatu seorang diri, alias "sakti". Rasa percaya diri yang tinggi sebenarnya hanya merujuk pada adanya beberapa aspek dari kehidupan individu tersebut dimana ia merasa memiliki kompetensi, yakin, mampu dan percaya bahwa dia bisa - karena didukung oleh pengalaman, potensi aktual, prestasi serta harapan yang realistik terhadap diri sendiri. ${ }^{12}$

Definisi yang diungkapkan di atas senada dengan beberapa definisi yang terdapat dalam situs-situs yang bertemakan Self Confidence yaitu:

Self-confidence is an attitude which allows individuals to have positive yet realistic views of themselves and their situations. Self-confident people trust their own abilities, have a general sense of control in their lives, and believe that, within reason, they will be able to do what they wish, plan, and expect.

Having self-confidence does not mean that individuals will be able to do everything. Self-confident people have expectations that are realistic. Even when some of their expectations are not met, they continue to be positive and to accept themselves. $^{13}$

Menurut penulis, dari beberapa definisi di atas dapat disimpulkan bahwa percaya diri adalah suatu sikap positif yang diyakini oleh individu terhadap kondisi diri sendiri dan lingkungan sekitarnya yang membuat ia bersedia untuk melakukan semua keinginan yang realistis dalam dirinya meskipun memiliki resiko.

\section{B. Pembahasan}

\section{Faktor Eksternal}

\section{a. Pola asuh orang tua (pendidikan rumah)}

Para ahli berkeyakinan bahwa kepercayaan diri bukanlah diperoleh secara instant, melainkan melalui proses yang berlangsung sejak usia dini, dalam kehidupan bersama orangtua. Meskipun banyak faktor yang mempengaruhi kepercayaan diri seseorang, namun faktor pola asuh dan interaksi di usia dini,

\footnotetext{
${ }^{11}$ Akrim Ridha, Menjadi Pribadi Sukses, Alih Bahasa: Tarmana Abdul Qasim (Bandung: Asy-Syamil, 2002), hal. 22.

${ }^{1212}$ Jacinta F. Rini, http://www.e-psikologi.com/DEWASA/161002.htm.

${ }^{13} \mathrm{http}: / /$ www.couns.uiuc.edu/brochures/self.htm.
} 
merupakan faktor yang amat mendasar bagi pembentukan rasa percaya diri. ${ }^{14} \mathrm{Hal}$ ini senada dengan apa yang diungkapkan oleh Gerald Corey dalam menemukan masalah-masalah yang muncul seperti: (1) Ketidak mampuan menaruh kepercayaan pada diri sendiri dan pada orang lain, ketakutan untuk mencintai dan untuk membentuk hubungan yang intim, dan rendahnya rasa harga diri; (2) ketidakmampuan mengakui dan mengungkapkan perasaan-perasaan benci dan marah, penyangkalan terhadap kekuatan sendiri sebagai pribadi, dan kekurangankekurangan perasaan-perasaan otonom; (3) ketidakmampuan menerima sepenuhnya seksualitas dan perasaan-perasaan seksualitas diri sendiri, kesulitan untuk menerima diri sendiri sebagai pria atau wanita, dan ketakutan terhadap seksualitas. Menurut pandangan psikoanalitik Freudian, ketiga area perkembangan personal dan sosial (cinta dan percaya, penanganan perasaan-perasaan negatif, dan pengembangan penerimaan yang positif terhadap seksualitas) itu berlandaskan lima tahun pertama kehidupan. ${ }^{15}$

Hal ini menunjukkan betapa pentingnya sikap orangtua, terhadap anak dengan menunjukkan perhatian, penerimaan, cinta dan kasih sayang serta kelekatan emosional yang tulus dengan anak, akan membangkitkan rasa percaya diri pada anak tersebut. Sementaraorangtua yang kurang memberikan perhatian pada anak, atau suka mengkritik, sering memarahi anak namun jika anak berbuat baik tidak pernah dipuji, tidak pernah puas dengan hasil yang dicapai oleh anak, atau pun seolah menunjukkan ketidakpercayaan mereka pada kemampuan dan kemandirian anak. Melalui tindakan perlindungan yang berlebihlebihanoverprotective, akan menghambat perkembangan kepercayaan diri pada anak karena anak tidak pernah diberi kesempatan untuk memecahkan masalahnya sendiri. Tindakan demikian, akanmembuat anak akan merasa, bahwa dirinya buruk, lemah, tidak dicintai, tidak dibutuhkan, selalu gagal, tidak pernah menyenangkan dan membahagiakan dirinya dan orangtua maupun orang lain. Anak akan merasa rendah diri di mata saudara kandungnya yang lain atau di hadapan teman-temannya.

\section{b. Lingkungan Masyarakat (pendidikan sosial)}

Perkembangan percaya diri akan meningkat atau lebih rendah juga berkembang melalui interaksi individu dengan lingkungannya. Lingkungan psikologis dan sosiologis yang kondusif akan menumbuhkan dan meningkatkan kepercayaan diri seseorang. Lingkungan psikologis dan sosiologis yang kondusif adalah lingkungan dengan suasana demokratis, yaitu adanya suasana penuh penerimaan, kepercayaan, rasa aman dan kesempatan untuk mengekspresikan ideide dan perasaan. Lingkungan psikologis dan sosiologis yang tidak kondusif adalah lingkungan dengan suasana penuh tuntutan, tidak menghargai pendapat orang lain dan tidak ada kesempatan untuk mengekspresikan ide dan perasaan. ${ }^{16}$

\footnotetext{
${ }^{14}$ Jacinta F. Rini, http://www.e-psikologi.com/DEWASA/161002.htm

${ }^{15}$ Gerald Corey, Teori dan Praktek Konseling dan Psikoterapi (Bandung: PT ERESCO, 1988), hal. 21.

${ }^{16}$ Tina Afiatin dan Sri Mulyani Martaniah, "Peningkatan Kepercayaan Diri Remaja Melalui Konseling Kelompok".Dalam jurnal Psikologika (Jogjakarta: Fakultas Psikologi UII, 1998), hal. 68-69.
} 
Anak yang tumbuh di tengah lingkungan masyarakat yang menghargai disiplin waktu, biasanya akan menjadi disiplin. Persaingan yang membudaya akan mendorong anggota-anggotanya bersifat ambisius, dan mungkin sulit mencintai orang lain. $^{17}$

\section{c. Lingkungan Pendidikan (pendidikan formal)}

Institusi pendidikan yang mengambil sebagian besar waktu pertumbuhan seseorang juga sangat mempengaruhi percaya diri. Siswa yang sering diperlakukan buruk (dihukum atau ditegur di depan umum) cenderung sulit mengembangkan percaya dirinya. Sebaliknya, yang sering dipuji, dihargai, diberi hadiah (apalagi di depan umum) akan lebih mudah mengembangkan konsep diri yang positif, sehingga lebih percaya diri. ${ }^{18}$

\section{Faktor Internal.}

Setelah dipaparkan di atas tentang beberapa faktor yang mempengaruhi munculnya rendah diri atau percaya diri seseorang, akan berakibat munculnya faktor internal yaitu faktor yang bersumber dari dirinya sendiri. Berupa pemahaman seseorang terhadap dirinya yang terdiri dari bagaimana orang tersebut memandang diri dan membuat gambaran tentang dirinya yaitu konsep diri.

Menurut Bambang Soenaryo, psi, PD erat kaitannya dengan konsep diri, menurutnya adalah cara pandang seseorang terhadap dirinya; baik dari sisi apa yang dipahami oleh dirinya sendiri, dari sisi apa yang dipahami oleh orang lain terhadap dirinya. Dan dari sisi nilai-nilai idealitas yang dituntut masyarakat secara umum terhadap dirinya. Yang penting adalah bagaimana seseorang memiliki konsep diri yang jelas. Dengan konsep diri yang jelas, seseorang akan mempercayai dirinya sendiri, mampu menilai posisi dan kualitas dirinya, serta dapat menempatkan diri dengan baik. ${ }^{19}$

\section{Percaya Diri dalam Al-Qur'an}

Setelah memiliki pemahaman bagaimana pandangan Islam tentang diri manusia yang sangat mulia dan istimewa, berikut ini menurut penulis merupakan tahapan-tahapan untuk dapat menjadi pribadi percaya diri yang dapat membawa kepada perubahan yang lebih baik. Tahapan-tahapan ini berdasarkan dari inti sari teori-teori yang dikemukan oleh ahli-ahli psikologi yang dicarikan padanannya melalui ayat-ayat al-Quran yang berbicara tentang konsep-konsep tersebut.

Jika disimpulkan dari berbagai karakteristik dan kiat meningkatkan percaya diri semuanya memiliki makna yang akan penulis pilih untuk kemudian dicari padanannya dalam konsep al-Qur'an sesuai dengan tema terebut, yaitu:

\section{Konsep Diri (ma'rifatunafsi)}

\footnotetext{
${ }^{17}$ Muhammad Anis Matta, Membentuk Karakter Cara Islam, (Jakarta: Al-I'tishom, 2002) hal. 35.

${ }^{18}$ Jannah, Izzatul, Everiday is PE DE Day, (Surakarta: Eureka, tt.), hal.28-29.

${ }^{19}$ Vieny, Dina, Rani, Membangun dan Mengasah PD, bahasan utama majalah UMMI Majalah Wanita. No4/XIV Agustus-September 2002/1423 H.hal11
} 
Konsep diri terdiri dari bagaimana kita melihat diri sendiri sebagai pribadi, bagaimana kita merasa tentang diri sendiri, dan bagaimana kita menginginkan diri sendiri menjadi manusia sebagaimana yang kita harapkan. ${ }^{20}$ Untuk meningkatkan rasa percaya diri manusia, tugas esensial yang harus dilakukan adalah mengenal diri sendiri. Bagaimana kondisi dirinya, bentuk fisik, sifat, hobi, kekuatan akal, dan kedudukannya. Al-Qur'an telah mendorong kepada manusia untuk memperhatikan dirinya sendiri, keistimewaannya dari makhluk lain, proses penciptaan dirinya, tentang hal ini Usman Najati teleh mengklasifikasikan ayat-ayat berikut untuk dijadikan renungan tentang siapa diri manusia.

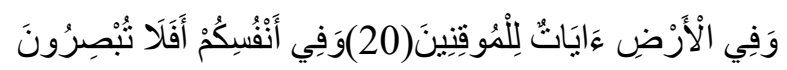

Dan di bumi itu terdapat tanda-tanda (kekuasaan Allah) bagi orang-orang yang yakin, (20) dan (juga) pada dirimu sendiri. Maka apakah kamu tiada memperhatikan? (QS, adz-Dzariyat, 51:20, 21)

Ibnu Katsir menafsirkan bahwa yang dimaksud ayat ini adalah bahwa di dunia ini telah terdapat tanda-tanda yang semuanya itu menunjukkan keagungan Sang Maha Pencipta dan kekuasaannya yang sangat luas, seperti bermacam-masam tumbuhtumbuhan, hewan-hewan, padang-padang, gunung-gunung, gurun-gurun, dan sungaisungai, dan perbedaan bahasa dan ras atau warna kulit pada manusia dan apa-apa yang terdapat dalam diri manusia yaitu akal, pemahaman, harkat, dan kebahagiaan. ${ }^{21}$

Adanya perbedaan dalam diri manusia inilah seharusnya membuat setiap manusia harus memperhatikan dirinya sendiri baik itu bentuk fisik, yang berkaitan dengan paras muka, jenis kelamin dan kejiwaan yang meliputi kecenderungan dan kekuatan jiwanya serta berkaitan dengan intelektual yaitu akal, pemahaman, harkat dan kesenangannya atas berbagai persoalan.

Karena perbedaan dalam diri manusia tersebut sangat penting kiranya manusia untuk memiliki konsep diri yang jelas baik itu berkaitan dengan fisik, kejiwaan dan kadar intelektual yang dimilikinya. Dengan mengetahui konsep diri yang jelas setiap individu akan mengetahui secara terfokus apa yang dapat mereka kontribusikan, ${ }^{22}$ untuk kemudian dapat mengoptimalkan potensi mereka yang telah dikaruniahi oleh Allah untuk menggapai kesuksesan dunia akhirat.

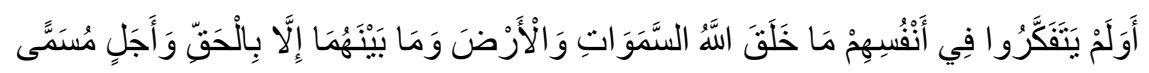

Dan mengapa mereka tidak memikirkan tentang (kejadian) diri mereka?

Allah tidak menjadikan langit dan bumi dan apa yang ada di antara keduanya melainkan dengan (tujuan) yang benar dan waktu yang ditentukan. (Ar Rum, 30: 8)

\footnotetext{
${ }^{20}$ Paul J. Centi, Mengapa Rendah Diri, Alih Bahasa: A.M. Hardjana, (Yogyakarta: Kanisius,1993)
}

\footnotetext{
${ }^{21}$ Lihat Tafsir Ibnu Katsir, Q.S.Adzariyat 20-21. Sakhr Software.

${ }^{22}$ H.M.Anis Matta,Model Manusia Muslim Pesona Abad ke-21, (Bandung : Asy Syamil,2002)
} 
Ayat di atas memiliki makna bahwa Allah menciptakan seluruh ciptaaanya dengan tujuan yang benar dan waktu yang telah ditentukan yang menurut Ibnu Katsir adalah hari kiamat. ${ }^{23}$ Berdasarkan ini, manusia seharusnya memikirkan dan merenungkan penciptaan Allah dalam diri mereka sendiri. Sehingga dapat mengetahui siapa dirinya dan apa yang harus ia perbuat semasa hidupnya karena seluruh hidup akan kembali kepada Sang Pencipta. Tentunya, berbuat kebaikan dengan beribadah dan memfungsikan peran sebagai khalifah merupakan satu-satunya pilihan dalam mengarungi bahtera kehidupan.

Meskipun kebaikan dan keburukan merupakan pilihan bagi manusia itu sendiri Al-Qur'an mememerintahkan manusia melakukan observasi dengan melakukan perjalanan untuk melihat dan menyaksikan bagaimana akibat yang diderita oleh orangorang yang mendustakan Rasulullah SAW. Ayat selanjutnya, QS Ar-Rum ayat 10 menjelaskan bahwa kegagalan dalam menjalani kehidupan dan apa yang akan diperoleh manusia baik itu kesuksesan maupun kegagalan adalah akibat tindakan mereka sendiri. $^{24}$

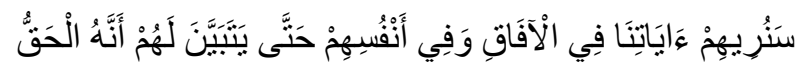

Kami akan memperlihatkan kepada mereka tanda-tanda (kekuasaan) Kami di segenap ufuk dan pada diri mereka sendiri, sehingga jelaslah bagi mereka bahwa Al Qur'an itu adalah benar (QS, Fushilat, 41: 53)

Allah SWT berfirman: "Bertaqwalah kepada Allah menurut ukuran kemampuanmu".QS.At-Taghabun ayat 16. sebagai contoh dalam Islam: perintahperintahnya sangatlah banyak, ibadah mahdah, belajar, berjihad, dan sebagainya. Tidak semua perintah dapat dikerjakan dengan sempurna. Oleh karena itu di surga disediakan banyak pintu ibadah sholat, zakat, haji, dan seterusnya. Dan karena kemampuan itulah setiap orang harus memilih fokus tertentu dalam kehidupannya. ${ }^{25}$

Ayat-ayat di atas merupakan suatu anjuran untuk memiliki konsep diri yang jelas berkenaan dengan pengetahuan tentang dirinya, bagaimana hakikat diri menurut dirinya sendiri (aku diri), peran dan tuntutan yang ada dalam masyarakat kepada dirinya (aku sosial). Dan bagaimana seharusnya aku menjadi sesuai muncul bagaimana ia dalam keidealannya (aku ideal). Dengan demikian menjadi penting untuk mengetahui konsep diri yang jelas agar dapat mengetahui secara terfokus yang dapat dikontribusikan dan dapat mengetahui sejauh mana seseorang memiliki arah atau tidak. Oleh karena itu menurut penulis, konsep diri merupakan komponen dasar yang harus dimiliki untuk memiliki kepercayaan diri. ${ }^{26}$

\section{Berpikir Positif (husnu dzhon)}

\footnotetext{
${ }^{23}$ Tafsir Ibnu Katsir,Sakhr Software

${ }^{24}$ Ibid

${ }^{25}$ Anis Matta, Model Manusia Muslim, Pesona Abad ke- 21, (Bandung: Asy-Syamil,2002) hal.19 2002)hal.18-29.

${ }^{26}$ Lihat.H.M.Anis Matta, Model Manusia Muslim, Pesona Abad ke-21(Bandung: Asyamil,
} 
Berpikir positif merupakan proses berpikir yang didasarkan kepada kajian terhadap faktor-faktor penyebab dan menetapkan alternatif yang mungkin berdasarkan pelbagai kemungkinan dengan meletakkan banyak pengganti. ${ }^{27}$ Berpikir positif berarti selalu memikirkan dan mengambil nilai-nilai positif dari berbagai situasi atau kondisi untuk kemudian mengambil tindakan yang tepat untuk mengatasinya.

Pemikiran yang positif akan melahirkan tindakan yang positif. Sebaliknya, pemikiran yang negatif, bahkan ragu-ragu, akan melahirkan tindakan yang negatif dan ragu-ragu pula sehingga tidak pernah menghasilkan sesuatu yang optimal. Kebanyakan orang berantakan pribadinya dan menuntut kehidupan yang sia-sia karena pikiranpikirannya kacau dan sikapnya negatif.

Berikut ini merupakan ayat-ayat yang menjelaskan hal tersebut.

\section{a. Berpikir positif dalam kondisi apapun}

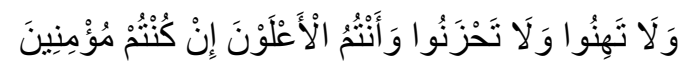

Janganlah kamu bersikap lemah, dan janganlah (pula) kamu bersedih hati, padahal kamulah orang-orang yang paling tinggi (derajatnya), jika kamu orang-orang yang beriman. (Ali imran: 139)

Ayat ini menjelaskan bahwa Allah menganjurkan kepada orang beriman untuk tidak menjadi lemah akibat kondisiyang yang mereka alami dan sesungguhnya keyakinan yang kuat akan berakibat kemenangan apabila kamu beriman kepada Allah. ${ }^{28}$ Hal ini senada dengan penafsiran al-Qurtubi yang menafsirkan agar kaum Muslim ketika perang Uhud tidak menjadi lemah dan penakut atas beban dan musibah yang sedang menimpa.

Peristiwa munculnya ketakutan umat Islam ketika menghadapi kekalahan pada perang Uhud-yang pada waktu itu mereka dikalahkan oleh tentara Quraisy yang dipimpin oleh Khalid bin Walid - adalah sebab turunnya ayat ini. Karena ketakutan itulah Allah menghibur mereka dengan menjanjikan mereka kemenangan yang lebih besar pada perang berikutnya pada masa kepemimpinan Rasulullah SAW dan juga para sahabat. ${ }^{29}$ Oleh sebab itu berpikiran positif dalam kondisi apapun walau itu berbentuk kematian, sudah seharusnya dimiliki oleh setiap diri manusia.

Ayat ini juga menunjukkan agar tidak iri hati terhadap keberhasilan yang dimiliki oleh orang lain.

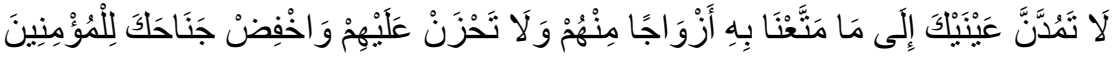

$$
\begin{aligned}
& \text { Janganlah sekali-kali kamu menujukan pandanganmu kepada } \\
& \text { keni 'matan hidup yang telah Kami berikan kepada beberapa golongan } \\
& \text { di antara mereka (orang-orang kafir itu), dan janganlah kamu bersedih } \\
& \text { hati terhadap mereka dan berendah dirilah kamu terhadap orang-orang } \\
& \text { yang beriman.(al-Hijr: 88) }
\end{aligned}
$$

${ }^{27}$ Akrim RidhaMenjadi Pribadi Sukses Panduan Melejitkan Potensi Diri, Alih Bahasa: Tarmana Abdul Qasim, (Bandung: Asy Syamil, 2002)hal.52

${ }^{28}$ Tafsir Ibnu Katsir, Sakhr Software

${ }^{29}$ Tafsir Qurthubi, Sakhr Software 
Janganlah engkau sekali-kali menunjukkan pandanganmu kepada kenikmatan hidup dan kebahagiaan duniawi yang telah kami berikan kepada kebeberapa golongan di antara orang-orang itu. Dan janganlah engkau beriri hati kepada mereka dan janganlah kecil hati dan sedih dan berendah dirilah kepada orang-orang mukmin. ${ }^{30}$ Ayat ini mengisyaratkan agar tetap percaya diri dengan kondisi diri, tanpa mereasa iri hati atas kekayaan atau keberhasilan yang dimiliki oleh orang lain.

\section{b. berpikir positif atas segala informasi yang diterima}

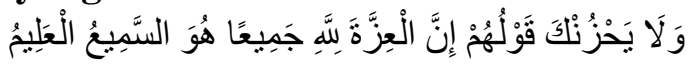

Janganlah kamu sedih oleh perkataan mereka. Sesungguhnya kekuasaan itu seluruhnya adalah kepunyaan Allah. Dialah Yang Maha Mendengar lagi Maha Mengetahui. (Yunus: 65)

Allah menegaskan kepada Rasulullah SAW agar tidak bersedih hati mendengar perkataan orang-orang musyrikin dan mohon pertolongan dan tawakallah hanya kepada Allah semata karena seluruh kekuasaan adalah milik Allah $^{31}$ dan juga jangan sedih atas ejekan dan pengingkaran mereka. ${ }^{32}$ Kritik yang dilontarkan seseorang terhadap orang lain atau diri sendiri bisa saja sebagai keuntungan jika diperhatikan dengan objektif, dengan menerimanya apabila jika kritik itu sesuai dengan masalah yang sedang dihadapi atau diabaikan karena tidak sesuai dengan keinginan tanpa harus merasa lemah atas ketidakmampuan diri. Yang diperlukan adalah bagaimana seseorang dapat memfokuskan pada tindakannya yang positif, sesuai dengan tuntunan al-Qur'an dan Sunnah yang menjadi dasar keyakinannya.

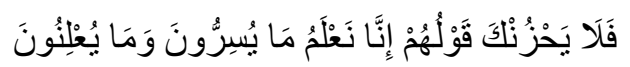

Maka janganlah ucapan mereka menyedihkan kamu. Sesungguhnya Kami mengetahui apa yang mereka rahasiakan dan apa yang mereka nyatakan. (Yasin: 76)

Janganlah engkau sedih hai Muhamamad SAW meskipun diejek dan diingkari atas kenabianmu yang engkau bawa dari sisi Tuhanmu. ${ }^{33}$ dan jangan sedih dengan perkataan mereka yang mengatakan bahwa ia adalah seorang penyair dan seorang tukang sihir. Ayat ini juga merupakan hiburan Allah kepada Rasulullah SAW agar tidak sedih terhadap hinaan, ejekan dan perkataan kaum Quraisy yang mengingkari kenabian Muhammad SAW.

Ayat-ayat di atas merupakan anjuran untuk yakin dengan diri sendiri berdasarkan nilai-nilai yang diyakini tanpa menghiraukan perkataan orang lain dan sikap orang lain terhadap dirinya. Kehidupan akan bisa dibina dengan baik

\footnotetext{
${ }^{30}$ Tafsir Ibnu Katsir, Sakhr Software

${ }^{31}$ Tafsir Ibnu Katsir,Sakhr Software

${ }^{32}$ Tafsir al-Qurthubi,Sakhr Software

${ }^{33}$ Tafsir Ibnu Katsir, Sakhr Software
} 
melalui cara berpikir yang benar, keyakinan yang teguh, dan tindakan yang tepat. ${ }^{34}$ berpikir positif dapat meningkatkan kepercayaan diri, jika diikuti dengan keyakinan dan tindakan.

\section{Berserah Diri (Tawakal)}

Tawakal berarti memasrahkan, mempercayakan segala urusan kepada Allah. ${ }^{35}$ Menurut Yusuf Qardhawi, menyerahkan diri sepenuhnya kepada Allah. Orang yang tawakal akan merasakan ketenangan dan ketentraman. Ia senantiasa merasa mantap dan optimis dalam bertindak. Di samping itu juga akan mendapatkan kekuatan spiritual, serta keperkasaan luar biasa, yang dapat mengalahkan segala kekuatan yang material. ${ }^{36}$ Perumpamaan tentang orang yang tawakal digambarkan oleh Buya Hamka bahwa bukanlah orang yang tawakal itu orang yang tidur dibawah pohon yang lebat buahnya seumpama buah durian. Karena kalau buah itu jatuh digoyang angin, dan orang yang tidur tersebut ditimpanya, itu adalah kesia-sian belaka. Contoh lainnya menurutnya adalah kalau bahaya datang dari sesama manusia, maka sekiranya ada jalan sabar, atau jalan yang mengelakkan diri atau menangkis, pilihlah dulu yang pertama, yaitu sabar. Kalau tidak dapat lagi pilihlah yang kedua yaitu mengelakkan diri. Kalau tidak dapat pula barulah menangkis. Kalau hanya tinggal jalan semata-mata menangkis, tidak juga ditangkis tidak lah bernama tawakal lagi tetapi sia-sia. ${ }^{37}$

Ayat ini merupakan bentuk tawakal yang dicontohkan oleh Rasulullah:

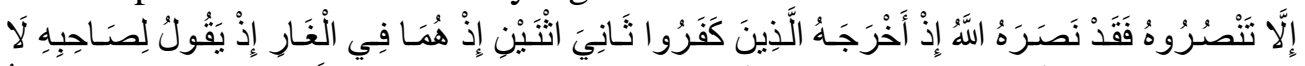

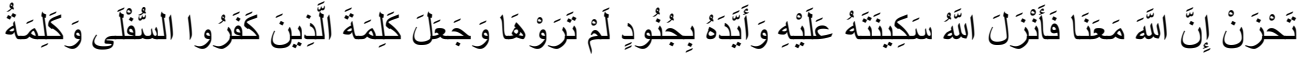

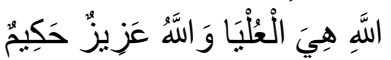

Jikalau kamu tidak menolongnya (Muhammad) maka sesungguhnya Allah telah menolongnya (yaitu) ketika orang-orang kafir (musyrikin Mekah) mengeluarkannya (dari Mekah) sedang dia salah seorang dari dua orang ketika keduanya berada dalam gua, di waktu dia berkata kepada temannya: "Janganlah kamu berduka cita, sesungguhnya Allah beserta kita." Maka Allah menurunkan ketenangan-Nya kepada (Muhammad) dan membantunya dengan tentara yang kamu tidak melihatnya, dan Allah menjadikan seruan orang-orang kafir itulah yang rendah. Dan kalimat Allah itulah yang tinggi. Allah Maha Perkasa lagi Maha Bijaksana.(at-Taubah: 40)

Ayat ini menjelaskan agar jangan takut berbagai macam serangan serangan hadapilah dengan tawakal kepada Allah. ${ }^{38}$ Hamka menggambarkan ayat di atas: Ingatlah seketika Rasulullah SAW meninggalkan negeri Makkah hendak ke Madinah.

\footnotetext{
${ }^{34}$ Norman V. Peale, Bila Anda Fikir Bisa Anda Pasti Bisa, Alih Bahasa. Wirmanjaya K. Liotohe (Jakarta: Gunung Jati, 1982), hal.196.

${ }^{35}$ Amatullah Amstrong, Khazanah Istilah Sufi, Kunci Memasuki Dunia Tasawuf (Bandung: Mizan,1996) hal. 188.

${ }^{36}$ Hasyim Muhammad. Dialog Antara Tasawuf dan Psikologi, Telaah atas Pemikiran Psikologi Humanistik Abraham Maslow (Yogyakarta: Pustaka Pelajar,2002) hal. 45-46.

${ }^{37}$ Hamka, Tasawuf Modern (Jakarta: Pustaka Panjimas, 1983), hal. 185.

${ }^{38}$ Tafsir Ibnu Katsir, Sakhr Software.
} 
Bersembunyi di dalam gua di atas bukit Jabal Tsur seketika dikejar oleh kafir Quraisy, berdua dengan sahabatnya Abu Bakar. Setelah bersembunyi dan tidak akan kelihatan musuh lagi, barulah ia berkata kepada sahabatnya itu: "Jangan takut, Allah bersama kita." Yaitu beserta mereka bersembunyi. Coba kalau Rasulullah SAW menyatakan dirinya, padahal musuhnya sebanyak itu, tentu menurut sunnatullah dia akan tertangkap atau binasa lantaran kesia-siannya. ${ }^{39}$ Pengalaman Rasulullah SAW tersebut, merupakan contoh untuk berbuat secara maksimal akan tetapi ketika mendapat ujian dan cobaan, umat Islam harus berserah diri hanya kepada Allah semata.

Berikut ini juga anjuran agar kita jangan membuat orang lain memiliki citra negatif terhadap dirinya yang dapat merendakan diri dan penafsiran tentang orang yang tawakal.

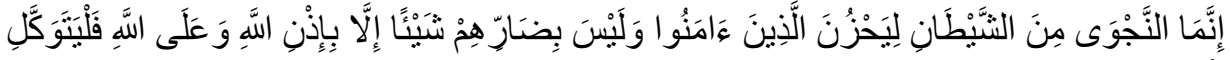

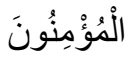

Sesungguhnya pembicaraan rahasia itu adalah dari syaitan, supaya orang-orang yang beriman itu berduka cita, sedang pembicaraan itu tiadalah memberi mudharat sedikitpun kepada mereka, kecuali dengan izin Allah dan kepada Allah-lah hendaknya orang-orang yang beriman bertawakkal.(al-Mujadilah: 10)

Berserah diri hendaknya hanya kepada Allah dalam ayat ini ditegaskan tentang larangan berbisik-bisik dihadapan orang lain karena akan menimbulkan kesedihan bagi orang mukmin yang lain. Dengan mengutip hadits rasul yang diriwayatkan oleh Shahihaini melalui Ibnu Umar bahwasanya Rasulullah saw berkata: apabila terdapat tiga orang yang berkumpul bersama janganlah keduanya berbisik-bisik tanpa sepengetahuan satu orang lainnya ${ }^{40}$ dan orang-orang yang beriman adalah orang yang bertawakal kepada Allah, dan meminta semua urusannya melalui pertolongan Allah, mohon perlindungan dari syetan dan kejahatan.

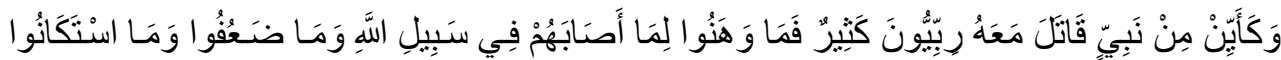

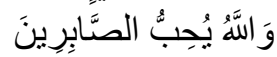

Dan berapa banyak nabi yang berperang bersama-sama mereka sejumlah besar dari pengikut (nya) yang bertakwa. Mereka tidak menjadi lemah karena bencana yang menimpa mereka di jalan Allah, dan tidak lesu dan tidak (pula) menyerah (kepada musuh). Allah menyukai orang-orang yang sabar. (Ali Imron: 146)

Allah membesarkan hati para mukminin dengan menghibur mereka akibat kekalahan mereka dalam perang Uhud; bahwa betapa banyaknya Nabi yang berperang dan bersama mereka, sahabat-sahabat mereka yang banyak bertakwa. Dan mereka tidak merasa lemah karena apa yang mereka alami dan derita di jalan Allah dan tidak

\footnotetext{
${ }^{39}$ Hamka, Tasawuf Modern (Jakarta: Pustaka Panjimas, 1983), hal. 186.

${ }^{40}$ Tafsir al-Qurthubi,Sakhr Software
} 
juga mereka merasa lesu atau menyerah. ${ }^{41}$ Inilah yang dimaksud tawakal yaitu adanya kemauan yang kuat dan usaha yang maksimal baru diiringi dengan tawakal faiza azamta fatawakkal 'alallah.

Kaitan tawakal dengan percaya diri adalah pada tindakan yang ia lakukan dengan usaha yang maksimal cara yang dihormatinya sendiri. Karena sadar bahwa ia tidak dapat selalu menang, ia menerima keterbatasannya. Akan tetapi selalu berusaha untuk mencapai sesuatu dengan usaha sebaik-baiknya, sehingga baik ia berhasil, gagal ataupun tidak berhasil dan tidak gagal, ia tetap memiliki harga dirinya. ${ }^{42}$

\section{Bersyukur ${ }^{43}$}

Setelah bertawakal kepada Allah dalam arti menyerahkan sepenuhnya kepada Allah dengan usaha yang maksimal. Untuk meningkatkan percaya diri perlu adanya rasa syukur untuk menimbulkan sikap positif dan perasaan menerima apa yang telah didapatkan dari tindakan yang dikerjakan kepada Allah SWT atas segala limpahan nikmat yang ia berikan.

Orang yang tidak bersyukur kepada Tuhan, ia adalah ibarat orang yang selalu melihat matahari tenggelam, tidak pernah melihat matahari terbit. Hidupnya dipenuhi dengan keluhan, rasa marah, iri hati dan dengki, kecemburuan, kekecewaan, kekesalan, kepahitan dan keputusasaan. Dengan "beban" seperti itu, bagaimana individu itu bisa menikmati hidup dan melihat hal-hal baik yang terjadi dalam hidupnya? Tidak heran jika dirinya dihinggapi rasa kurang percaya diri yang kronis, karena selalu membandingkan dirinya dengan orang-orang yang membuat "cemburu" hatinya. Oleh sebab itu, belajarlah bersyukur atas apapun yang dialami dan percayalah bahwa Tuhan pasti menginginkan yang terbaik untuk hidup setipa hamba-Nya. ${ }^{44}$

Menurut Al-Ghazali, mengapa manusia harus bersyukur terdapat dua sebab.

1. Agar kekal kenikmatan yang sangat besar itu. Sebab jika tidak disyukuri, akan hilang.

2. Agar nikmat yang telah kita dapatkan bertambah. ${ }^{45}$

Bentuk nyata dari syukur salah satunya adalah dengan mengucapkan pujipujian alhamdulillah, kata-kata ini dapat diibaratkan dengan self-affirmation ${ }^{46}$ sebagai pengungkapan positif atas kondisi diri yang dapat meningkatkan percaya diri.

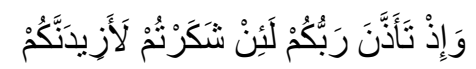

Dan (ingatlah juga), tatkala Tuhanmu mema lumkan: "Sesungguhnya jika

kamu bersyukur, pasti Kami akan menambah (ni`mat) kepadamu,(QS.Ibrahim: 7)

Para ahlul jannah nantinya akan mengucapkan syukur kepada Allah yang telah menghilangkan kesedihan mereka dan mereka mengakui akan ke-Maha Pengampunan

${ }^{41}$ Tafsir Ibnu Katsir, Sakhr Software.

${ }^{42}$ lihat bab II tentang karakteristik Pribadi PD Herbert Fensterheim PH.D. dan Jean Baer, Jangan Bilang :Ya" Bila Anda Akan Mengatakan "Tidak" (Jakarta : Gunung Jati, 1980) hal. 14-15.

${ }^{43}$ Lihat.An-Nahl: 112; an-Nisa': 147; Ibrahim: 7; dan lain-lain.

${ }^{44}$ Ibid.

${ }^{45}$ Imam Al-Ghazali, Minhajul Abidin, Alih Bahasa: Abul Hiyadh. (Surabaya: Mutiara Ilmu,), hal.351.

${ }^{46}$ Lihat bab II, dikutip dari Jacinta F. Rini,http://www.e-psikologi.com 
dan Maha mensyukuri Allah. Jika umat Islam ingin menjadi ahlul jannah tentunya saat ini umat Islam harus mensyukuri segala nikmat yang telah dikaruniakan Allah kepada mereka.

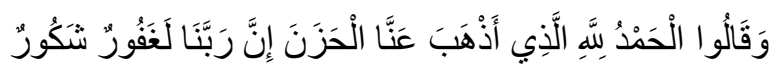

Dan mereka berkata: "Segala puji bagi Allah yang telah menghilangkan duka cita dari kami. Sesungguhnya Tuhan kami benarbenar Maha Pengampun lagi Maha Mensyukuri.(Faathir: 34)

\section{Evaluasi Diri (Muhasabah)}

Orang yang percaya kepada dirinya sendiri, tidak merasa hina apa yang dikerjakannya, bahkan dia ingin supaya memperoleh kemajuan dalam pekerjaannya itu. Gustav Le Bone berkata: "orang yang percaya diri tidaklah mengharap pujian manusia. Orang yang mengharap pujian, niscaya ragu-ragu akan harga dirinya." ${ }^{47}$ Sudahkah diri anda percaya diri? tentunya setiap individu sendiri yang dapat menilai hal tersebut berdasarkan konsep percaya diri. Untuk itu, perlu adanya muhasabah diri, self reflection atau self evaluate agar dapat mengevaluasi keberhasilan dan kegagalan yang pasti kita hadapi dalam kehidupan, utuk kemudianmemperbaikinya.

Evaluasi Diri adalah salah satu ajaran yang dianjurkan Islam kepada umatnya dalam setiap hari untuk selalu mengevaluasi diri agar hari esok lebih baik dari hari ini.

Allah swt berfirman:

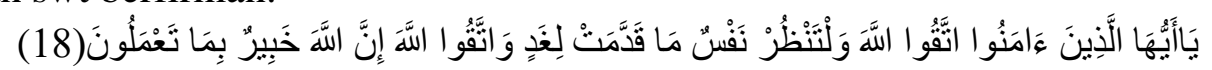

Hai orang-orang yang beriman, bertakwalah kepada Allah dan hendaklah setiap diri memperhatikan apa yang telah diperbuatnya untuk hari esok (akhirat), dan bertakwalah kepada Allah, sesungguhnya Allah Maha Mengetahui apa yang kamu kerjakan.(al-Hasyr:18)

Menurut Danah Zohar dan Ian Marshal dalam karya mereka SQ. Banyak di antara manusia yang tidak pernah merenung. Mereka hanya hidup dari hari ke hari, dari aktifitas ke aktifitas, dan seterusnya. SQ yang lebih tinggi berarti sampai pada kedalaman dari segala hal, memikirkan segala hal, menilai diri sendiri dan perilaku dari waktu ke waktu. Paling baik dilakukan setiap hari. Ini dapat dilakukan dengan menyisihkan beberapa saat untuk berdiam diri, bermeditasi setiap hari, bekerja dengan penasihat atau ahli terapi, atau sekedar mengevaluasi setiap hari sebelum anda jatuh tertidur di amalam hari. ${ }^{48}$ Ungkapan Umar yang sangat masyhur yaitu haasibuu anfusakum qobla an tuhaasibuu perlu kiranya dapat diaplikasikan dalam kehidupan nyata.

Dengan Muhasabah seseorang akan dapat lebih memahami kondisi dirinya Jika anda mati minggu depan apa yang ingin anda bisa katakan mengenai apa apa

\footnotetext{
${ }^{47}$ Hamka, Pribadi (Jakarta: Bulan Bintang, 1982), hal.71.

${ }^{48}$ Danah Zohar dan Ian Marshal, SQ, Memanfaatkan Kecerdasan Spiritual dalam Berpikir Integralistik dan Holistik untuk Memaknai Kehidupan(Bandung: Mizan,2002) Cet.V.hal.232
} 
yang telah anda capai atau sumbangkan pada kehidupan? Jika anda diberi waktu setahun lagi, apa yang akan anda lakukan dengan waktu tersebut.? ${ }^{49}$ Sebaiknya apa yang dievaluasi hendaknya tertulis jelas jangan hanya ada dalam pikiran. Untuk meningkatkan kualitas diri perlu adanya target-target yang akan dicapai untuk mempermudah melakukan evaluasi.

\section{Kesimpulan}

Percaya diri adalah suatu sikap positif seorang individu yang memampukan dirinya untuk mengembangkan penilaian positif baik terhadap diri sendiri maupun terhadap lingkungan/situasi yang dihadapinya. ${ }^{50}$ Sehingga dengan alasan inilah ia akan mampu melakukan tindakan sesuai dengan apa yang ia inginkan, rencanakan dan ia harapkan. Islam menghendaki agar umatnya menjadi orang-orang yang beriman dan percaya diri. Akan tetapi, percaya diri dalam Islam bukanlah bersumber dari gambaran tubuh (body image) dan gambaran sosial (sosial image) semata. Melainkan keyakinan terhadap diri sendiri yang berlandaskan pada keimanan kepada Allah swt. Sehingga keyakinan terhadap apa yang dilakukan oleh dirinya harus sesuai dengan tuntunan al-Qur'an dan Sunnah.

Percaya diri dalam Al-Qur'an bertitik tolak dari konsepsi yang mulia terhadap manusia yaitu sebagai Khalifah Allah, sebaik-baiknya makhluk ciptaan, dan makhluk yang bebas berkehendak. Konsep percaya diri dalam al-Qur'an dimulai dengan memiliki konsep diri yang jelas bagaimana ciri-ciri fisik, sifat-sifat, hoby, kekuatan, kelemahan, dan mengetahui kewajiban yang harus dilakukan sesuai dengan kedudukan. Kemudian, setelah memiliki konsep diri yang jelas bahwa individu itu adalah seorang muslim yang memiliki ciri-ciri fisik, sifat, dan karakter yang khas ia harus; berpikir positif terhadap diri, situasi dan lingkungan yang ada di sekitarnya. Setelah itu, setiap manusia harus yakin bahwa dirinya memiliki potensi yang diberikan oleh Allah sebagai makhluk pilihan terbaik yang diciptakan-Nya. Keyakinan ini, tidak cukup jika hanya keyakinan tanpa adanya tindakan yang membuktikan semua itu melainkan dibuktikan dengan tindakan (iman dan amal). Dalam melakukan tindakan hendaknya dengan usaha yang maksimal sesuai dengan potensi yang dimiliki. Apapun hasil yang didapatkan melalui tindakan yang dilakukan asalkan sesuai dengan keinginan, cita-cita dan harapan yang tidak bertentangan dengan Al-Qur'an dan Sunnah. Maka, berdoa dan tawakallah kepada Allah karena ia akan menenangkan jiwa. Setelah yakin bahwa semua yang terjadi di muka bumi ini telah teratur dengan sendirinya, hal lain yang harus dilaksanakan adalah bersyukur, karena ia akan meningkatkan rizki. Terakhir, muhasabah atau evaluasi diri merupakan suatu kewajiban bagi setiap muslim. Untuk mengetahui kualitas keimanan kepada Allah dan seluruh amal perbuatan yang dilakukan. Serta untuk mengetahui kekuatan, kelemahan, potensi, kekurangan sehingga hari-hari yang akan datang lebih baik dari hari ini.

\footnotetext{
${ }^{49}$ Ibid.

${ }^{50}$ Jacinta F. Rini,http://www.e-psikologi.com/DEWASA/161002.htm.
} 


\section{DAFTAR PUSTAKA}

Afiatin, Tina, dan Sri Mulyani Martaniah, Peningkatan Kepercayaan Diri Remaja Melalui Konseling Kelompok. dalam Jurnal Psikologika (Yogyakarta: Fakultas Psikologi UII, 1998).

Al Qurthubi, Abu Abdullah, Tafsir al-Qurthubi, Sakhr Software.

Amstrong, Amatullah, Khazanah Istilah Sufi, Kunci Memasuki Dunia Tasawuf (Bandung: Mizan,1996)

Angelis, Barbara De, Confidence, Percaya diri, Sumber Sukses dan Kemandirian (Jakarta: Gramedia Pustaka Utama, 2002).

Badri, Malik B, Dilema Psikolog Muslim, Alih Bahasa: Siti Zainab Luxfiati, (Jakarta: Pustaka Panjimas, 1986)

Centi, Paul J., Mengapa Rendah Diri, Alih Bahasa: A.M. Hardjana, (Yogyakarta: Kanisius, 1993).

Corey, Gerald, Teori dan Praktek Konseling dan Psikoterapi (Bandung: PT ERESCO, 1988)..

Ghazali, Imam, Minhajul Abidin, Alih Bahasa: Abul Hiyadh. (Surabaya: Mutiara Ilmu,).

Hamka, Pribadi (Jakarta: Bulan Bintang, 1982).

Hamka, Tasawuf Modern (Jakarta: Pustaka Panjimas, 1983).

Hasyim, Muhammad. Dialog Antara Tasawuf dan Psikologi, Telaah atas Pemikiran Psikologi Humanistik Abraham Maslow (Yogyakarta: Pustaka Pelajar,2002)

Izzatul,Jannah ,Everiday is PE DE Day, (Surakarta: Eureka, tt.)

Katsir, Ismail Bin, Tafsir Ibnu Katsir, Sakhr Software.

Matta,Muhammad Anis, Membentuk Karakter Cara Islam, (Jakarta: Al-I'tishom, 2002)

Peale, Norman V., Bila Anda Fikir Bisa Anda Pasti Bisa, Alih Bahasa. Wirmanjaya K. Liotohe (Jakarta: Gunung Jati, 1982).

Ridha, Akrim, Menjadi Pribadi Sukses, Alih Bahasa: Tarmana Abdul Qasim (Bandung: Asy-Syamil, 2002)

Supratikya. A, Teori-Teori Holistik (Organismik-Fenomenologis), (Yogyakarta: Kanisius, 1993)

Usman, Muhamad Najati, Al-Qur'an dan Psikologi. Alih Bahasa: Tb. Ade Asnawi Syihabuddin (Jakarta: Aras Pustaka, 2002)

Vieny, Dina, Rani, Membangun dan Mengasah PD, bahasan utama majalah UMMI Majalah GEWanita. No4/XIV Agustus-September 2002/1423.

Wiyarno, Budi, Be Your Self, makalah pada seminar Becoming Self Confident di Universitas Ahmad Dahlan Yogyakarta. 2002

Zohar, Danah dan Ian Marshal, SQ, Memanfaatkan Kecerdasan Spiritual dalam Berpikir Integralistik dan Holistik untuk Memaknai Kehidupan (Bandung: Mizan,2002).

http://www.hidayatullah.com/sahid/9901/marah.htm

http://www.indomedia.com/Intisari/2000/februari/pede.htm 